\title{
ETHANOLIC EXTRACT OF ALGERIAN PROPOLIS INDUCED CELL DAMAGE IN STAPHYLOCOCCUS AUREUS: A PROMISING ALTERNATIVE AS A NATURAL BIO-PRESERVATIVE IN FOOD PRODUCTS
}

\author{
I. K. Bedaida* ${ }^{a *}$ S.H.D. Masry ${ }^{\text {b,c }}$, B. Mamache ${ }^{d}$, M.G. Shehata ${ }^{e}$, L. Benammar ${ }^{a}$, \\ and A. AYACHI ${ }^{\mathrm{f}}$ \\ a Department of Microbiology and Biochemistry, Faculty of Natural and Life Sciences, University of Batna 2, \\ 05000 Batna. Algeria \\ ${ }^{\mathrm{b}}$ Department of Plant Protection and Biomolecular Diagnosis, Arid Lands Cultivation Research Institute, City of \\ Scientific Research and Technological Applications (SRTA-City), 21934 Borg El-Arab, Alexandria. Egypt \\ ${ }^{\mathrm{c}}$ ADAFSA, Research and Development Division, Al Ain. UAE \\ ${ }^{\mathrm{d}}$ Laboratory of Environment and Animal Health and Productions (EAHP), Veterinary and Agronomic Sciences \\ Institute, University of Batna 1, 05000 Batna. Algeria \\ e Department of Food Technology, Arid Lands Cultivation Research Institute, City of Scientific Research and \\ Technological Application (SRTA-City), 21934 Borg El-Arab, Alexandria. Egypt \\ ${ }^{\mathrm{f}}$ Department of Veterinary Sciences, of Veterinary and Agronomic Sciences Institute, University of Batna 1, 05000 \\ Batna. Algeria
}

(Received: 14 May 2020; accepted: 2 July 2020)

This study describes the antistaphylococcal mechanism of the ethanolic extract of Algerian propolis on Staphylococcus aureus ATCC 25923. To investigate the underlying mechanism of action of the ethanolic extract of propolis, bacteriolysis, bacterial death, leakage of potassium, proteins, nucleic components, and scanning electron microscopic studies were conducted. The results showed that the minimum inhibitory concentration (MIC) of ethanolic extract of propolis against Staphylococcus aureus ATCC 25923 was $39 \mu \mathrm{g} \mathrm{ml}^{-1}$. The extract displayed significant bactericid activity against $S$. aureus in a time and concentration dependant manner. Its mode of action was evident from the increase of $\mathrm{K}^{+}$efflux and nucleotide leakage. These results were confirmed by Scanning Electron Microscopy (SEM) that showed remarkable morphological and ultrastructural changes in S. aureus after exposure to $1 \mathrm{MIC}$ and $2 \mathrm{MIC}$ concentrations. The overall study contributed to the understanding of the antistaphylococcal mechanism of ethanolic extract of propolis. It emphasizes its potential to be used as an important natural bio-preservatives in food products.

Keywords: propolis, food safety, Staphylococcus aureus, antimicrobial, cytoplasmic leakage, morphological damage

Propolis is a resinous material collected by honeybee workers from plant exudates. It has been used from the ancient times as a biocide against fungi and invasive bacteria (MOHDALY et al., 2015). Propolis possesses various properties, such as antioxidant, anti-inflammatory, antitumor, immunostimulatory, and antimicrobial activities (EL-SoHAIMY \& MASRY, 2014; SolTANi et al., 2017). This latter is highly attributed to flavonoids (Mirzoeva et al., 1997) and phenolic acids, such as caffeic and ferulic acids (MoHDaLY et al., 2015).

Studies have shown that ethanolic extract of propolis (EEP) is effective at inhibiting Gram-positive bacteria, especially Staphylococcus aureus (PEDONESE et al., 2019), which is considered as the third most prevalent cause of food poisoning in the world (ZHANG et al., 1998).

\footnotetext{
* To whom correspondence should be addressed.

Phone: +213771391415 ; e-mail: ibtissem.bedaida@univ-batna2.dz
} 
In the past, chemical preservatives were used for the inhibition of these harmful microorganisms, but microbial adaptation and evolution enhanced resistance to chemical preservatives and antibiotics, which made the situation increasingly worse (KouTsoumANIS $\&$ Sofos, 2004). That is why recent research is focusing on the use of EEP as a preservative in different food products (SURIYATEM et al., 2018; PeDONESE et al., 2019) in an attempt to search for natural drugs with an evident antimicrobial activity.

Despite the large number of studies dealing with the antimicrobial activity of propolis (BENHANifia et al., 2014; El-Guendouz et al., 2018), little work has been done concerning its mode of action. Since the mechanism of action of propolis seems to be complex, an attempt has been made to explore for the first time the possible mode of action of the ethanolic extract of Algerian propolis against S. aureus ATCC 25923 using several physiological indices in order to use it as a safe natural bio-preservative in different food products.

\section{Materials and methods}

\subsection{Propolis sample}

The Algerian propolis was obtained from Batna region/Algeria (North-Eastern Algeria). The sample $(30 \mathrm{~g})$ was extracted with a $70 \%$ ethanol solution $(300 \mathrm{ml})$ by mixing for 7 days at room temperature. The ethanolic extract of propolis (EEP) was recovered by filtration and dried under vacuum using a rotary evaporator. However, the analysis and the experiments were conducted at the labs of Department of Plant Protection and Biomolecular diagnosis and Department of Food Technology, Arid Lands Cultivation Research Institute, City of Scientific Research and Technological Application (SRTA-City), Borg El-Arab, Alexandria, Egypt.

\subsection{Microorganism}

Determination of minimum inhibitory concentration (MIC) was carried out on two reference strains, Staphylococcus aureus ATCC 25923 and Staphylococcus aureus NTCC 10766, and one clinically isolated methicillin resistant Staphylococcus aureus. Staphylococcus aureus ATCC 25923 was used to investigate the bactericidal mode of action of EEP.

\subsection{HPLC Analysis}

HPLC analysis was carried out using an Agilent 1260 Series equipment. The separation was carried out using $\mathrm{C} 18$ column $(250 \mathrm{~mm} \times 4.6 \mathrm{~mm}$ i. d., $5 \mu \mathrm{m})$. The mobile phase consisted of water (A) and $0.02 \%$ trifluoro-acetic acid in acetonitrile (B) at a flow rate $1 \mathrm{ml} \mathrm{min}^{-1}$. The mobile phase was programmed consecutively in a linear gradient as follows: 0 min $(80 \% \mathrm{~A})$; $0-5 \min (80 \% \mathrm{~A}) ; 5-8 \min (40 \% \mathrm{~A}) ; 8-12 \min (50 \% \mathrm{~A}) ; 12-14 \min (80 \% \mathrm{~A})$, and $14-16 \mathrm{~min}$ $(80 \% \mathrm{~A})$. The column was operated at $35^{\circ} \mathrm{C}$. The injection volume was $10 \mu \mathrm{l}$ and the detection was set at $280 \mathrm{~nm}$.

\subsection{Determination of the minimum inhibitory and bactericidal concentrations (MIC, MBC)}

The assays were performed using methods of AKINPELU and co-workers (2016). The MIC value was determined using the agar dilution method. A serial of twofold dilutions of EEP were studied in plates containing Mueller Hinton agar. The final concentrations obtained ranged from 1000 to $19.5 \mu \mathrm{g} \mathrm{ml}^{-1}$. The plates were incubated at $37^{\circ} \mathrm{C}$ for $24 \mathrm{~h}$. The MIC 
value was defined as the lowest concentration of propolis that resulted in no visible growth or haze. For MBC, samples were taken from plates with no visible growth in MIC assay and sub-cultured on plates containing nutrient agar. The plates were incubated at $37{ }^{\circ} \mathrm{C}$ for $72 \mathrm{~h}$. The concentration of the plate that did not exhibit any bacterial growth was taken as MBC.

\subsection{Bacterial killing assay}

The killing assay was performed according to the procedure of TYAGI and co-workers (2015). An inoculum of $10^{6} \mathrm{CFU} \mathrm{ml}^{-1}$ of $S$. aureus phosphate buffered saline (PBS) suspension was exposed to different concentrations of EEP relative to the MIC. Aliquots were taken over 24 $\mathrm{h}$ intervals, placed on PCA (Plate Count Agar) plate in triplicate and incubated at $37{ }^{\circ} \mathrm{C}$ for $24 \mathrm{~h}$. Time-kill curves were realised by plotting $\log _{10} \mathrm{CFU} \mathrm{ml} \mathrm{m}^{-1}$ against time (h).

\subsection{Bacteriolysis and nucleic leakage}

To study the integrity of cell membrane, bacteriolysis and nucleic leakage were carried out using the method of IFESAN and co-workers, (2009) with slight modifications. Cells of $S$. aureus from $18 \mathrm{~h}$ old BHI broth culture were washed, resuspended in PBS $\left(5 \times 10^{8}\right.$ cells $)$. The suspensions were treated with different concentrations relative to the MICs. Samples were taken at various time intervals for $2 \mathrm{~h}$, and the ODs ${ }_{620}$ were measured immediately. For 260 $\mathrm{nm}$ absorbing materials, the mixture was centrifuged and the $\mathrm{OD}_{260}$ of the supernatant was measured. S. aureus incubated with PBS alone and with vancomycin was used as control.

\subsection{Potassium $\left(K^{+}\right)$and protein leakages}

The potassium and protein leakages were performed according to the method of AKINPELU and co-workers (2015). S. aureus cells were cultured overnight at $37^{\circ} \mathrm{C}$. The cells were washed, and then resuspended in PBS to achieve $5 \times 10^{8}$ cells $\mathrm{ml}^{-1}$. The suspensions were incubated with various concentrations of EEP relative to the MIC. Samples were taken at various time intervals for 2 h. S. aureus incubated with PBS alone and with vancomycin were used as control. Each suspension was then centrifuged at $10000 \times g$ and assayed for potassium ions using atomic absorption spectroscopy, and at $5000 \times \mathrm{g}$, in which supernatants collected were assayed for protein using the Bradford method for protein quantification (BIO-BASIC). The assays were carried out in triplicate.

\subsection{Scanning electron microscopy (SEM)}

After treatment of $S$. aureus cell suspension with different concentrations of EEP relative to the MIC in PBS for $2 \mathrm{~h}$, the suspension was centrifuged at $1792 \times \mathrm{g}$ for $10 \mathrm{~min}$, washed with PBS ( $\mathrm{pH}=7.4)$ three times, and fixed for $2 \mathrm{~h}$ at $4{ }^{\circ} \mathrm{C}$ with glutaraldehyde. After fixation, the cells were washed three times in PBS and dehydrated in series of graded ethanol (20-95\%). The dehydrated cells were finally dissolved in $100 \%$ ethanol and dried under vacuum. The cells were coated with $15 \mathrm{~nm}$ gold particles through automatic sputter coater. The samples were then viewed through SEM (JEOL JSM-6360 LA).

\subsection{Statistical analysis}

Statistical analysis was performed using the one-way analysis of variance (ANOVA) followed by Tukey's post hoc test for the determination of statistical significance between groups using $\mathrm{R}$ software. Values shown are mean $\pm \mathrm{SD}$. 


\section{Results and discussion}

\subsection{HPLC analysis of phenolic and flavonoid compounds}

Despite the great chemo-diversity of propolis, no specific compounds could be associated with the antimicrobial activity of propolis extract. Results of the phenolics and flavonoids profiles are presented in Table 1. A chromatogram is shown as Supplement available only online. Many other researchers have studied the phenolic profile of Algerian propolis from other regions. Results showed that caffeic acid derivatives were present in all Algerian propolis samples studied (BenHANIFIA et al., 2014; SolTANI et al., 2017). Flavonoids like chrysin, pectolinarigenin, pilosin, apigenin, pinobanksin, and galangin were also found (SEgueni et al., 2016; Soltani et al., 2017). Some qualitative similarities were observed between Algerian EEP and the ethanolic extract of Egyptian propolis (EL-SoHAIMY \& MASRY, 2014).

Table 1. HPLC analysis of phenolic and flavonoid compounds of Algerian propolis

\begin{tabular}{lc}
\hline Compounds & $\begin{array}{c}\text { Concentration } \\
\left(\mathrm{mg} \mathrm{g}^{-1}\right)\end{array}$ \\
\hline Gallic acid & 0.05 \\
Chlorogenic acid & 0.05 \\
Catechin & 0.14 \\
Caffeine & 0.01 \\
Coffeic acid & 0.30 \\
Syringic acid & 0.05 \\
Rutin & 0.13 \\
Pyrocatechol & 0.08 \\
Ellagic acid & 0.00 \\
Coumaric acid & 0.07 \\
Vanillin & 0.06 \\
Ferulic acid & 0.05 \\
Naringenin & 0.58 \\
Propyl gallate & 0.39 \\
4,7-Dihydroxy isoflavone & 0.67 \\
Quercetin & 1.90 \\
Cinnamic acid & 0.34 \\
\hline
\end{tabular}

The mechanism of action of propolis seems to be complicated and depends strongly on its chemical composition. The investigated sample showed the presence of hydroxybenzoic acid, which causes significant changes in the bacterial physiochemical properties (BORGES et al., 2013). Ferrulic and caffeic acids are responsible for the inhibition of bacterial growth and proliferation (Popova et al., 2017). Cinnamic acid uncouples the energy transducing cytoplasmic membrane and inhibits bacterial motility (Mirzoeva et al., 1997). Naringenin and rutin disrupt bacterial cytoplasmic membrane (CUSHNIE \& LAMB, 2005).

\section{2. $M I C$ and $M B C$}

Our propolis revealed a strong activity against the three tested strains of $S$. aureus. The same results were observed for the three strains $\left(\mathrm{MIC}=39 \mu \mathrm{g} \mathrm{ml}^{-1}, \mathrm{MBC}=78 \mu \mathrm{g} \mathrm{ml}^{-1}\right.$ ). In fact, a 
MIC $100<100 \mu \mathrm{g} \mathrm{ml}^{-1}$ should be considered as a promising value for crude extract (Ríos \& RECIO, 2005). This result is much lower than those obtained for Polish (GRECKA et al., 2019) and Moroccan propolis (EL-GuENDouz et al., 2018) with $0.39-0.78 \mathrm{mg} \mathrm{ml}^{-1}$ and $0.36 \mathrm{mg} \mathrm{ml}^{-1}$. On the other hand, Algerian propolis from Elmalha (SEGUENI et al., 2014) exhibited a MIC value very close to our tested propolis with $40 \mu \mathrm{g} \mathrm{ml}^{-1}$.

\subsection{Bacterial killing assay}

Most reported studies are based on the determination of MICs and MBCs, but that way it is not possible to determine how quickly an agent acts on the organisms. That is why time-kill determination was conducted over $24 \mathrm{~h}$ with different concentrations in order to determine the required contact time.

The treatment with EEP at $1 \mathrm{MIC}, 2 \mathrm{MIC}$, and $4 \mathrm{MIC}$ concentrations eradicated S. aureus cells in a time and concentration dependant manner. The eradication was achieved completely in $24 \mathrm{~h}, 6 \mathrm{~h}$, and $2 \mathrm{~h}$ for $1 \mathrm{MIC}, 2 \mathrm{MIC}$, and $4 \mathrm{MIC}$, respectively (Fig. 1). These results for the different concentrations are very promising, considering that bactericidal effect is defined as a $3 \log$ decrease in the CFU ml ${ }^{-1}$ or $99.9 \%$ over a specified time (MAY et al., 2000). The viability of untreated cells remained stable.

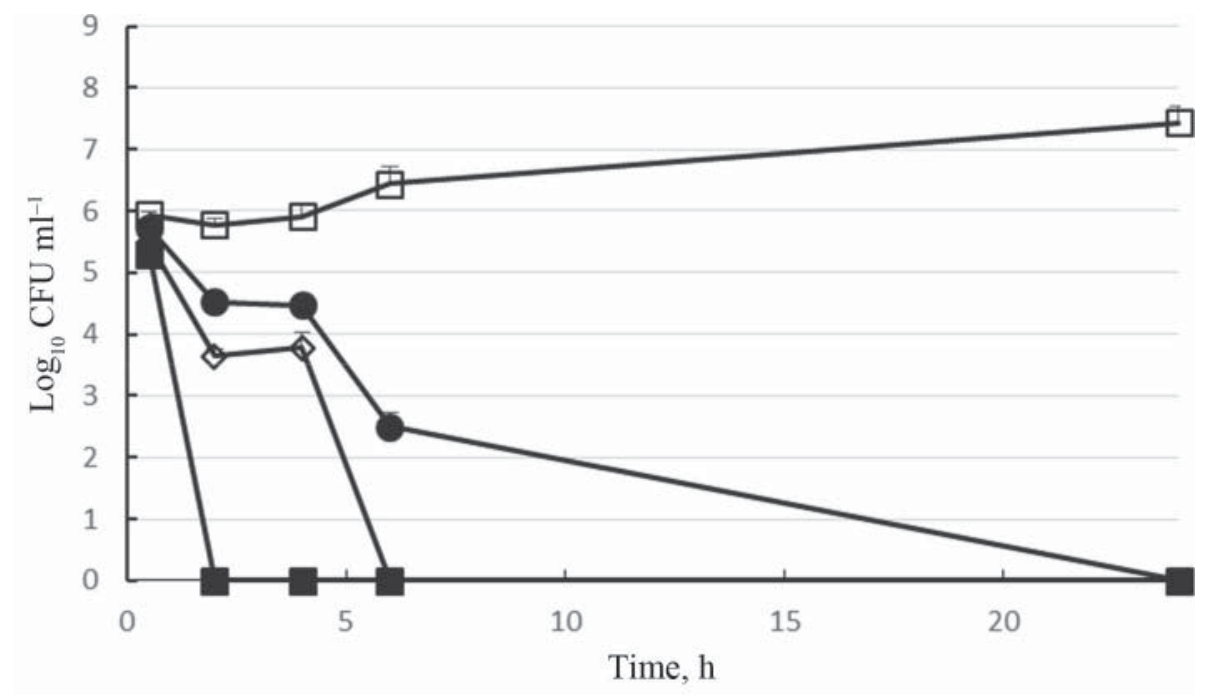

Fig. 1. The effect of EEP on death kinetics of $S$. aureus

$(\square)$ : Control without EEP; $(\bullet)$ : cells at $1 \mathrm{MIC} ;(\diamond)$ : cells at $2 \mathrm{MIC}$; $(\bullet)$ : cells at 4MIC

\subsection{Bacteriolysis and nucleic leakage}

The exposure of S. aureus to $1 \mathrm{MIC}, 2 \mathrm{MIC}$, and $4 \mathrm{MIC}$ concentrations of EEP reduced the $\mathrm{OD}_{620}$ of $S$. aureus suspensions after $120 \mathrm{~min}$ of contact to $95.70 \% \pm 0.05,94.35 \% \pm 0.03$, and $91.90 \% \pm 0.06$, respectively, compared to the original. The untreated cells presented an $\mathrm{OD}_{620}$ of $99.28 \%$ of the original. For the vancomycin $\left(0.5 \mathrm{mg} \mathrm{ml}^{-1}\right)$, the $\mathrm{OD}_{620}$ was $88.29 \% \pm 0.05$ of the original. These results revealed that EEP mechanism of action is not related to the cell wall, as no differences were detected between $\mathrm{OD}_{620} \mathrm{~nm}$ of treated and non-treated cells (IFESAN et al., 2009). 
The extent of damage to the cell membrane was also studied through nucleic leakage that absorbs UV light at $260 \mathrm{~nm}$. S. aureus cells treated with EEP at 4MIC produced higher $\mathrm{OD}$ values at 60 min compared to the control (Fig. 2). Similarly, an increase in $\mathrm{OD}_{260}$ was observed with $1 \mathrm{MIC}$ and $2 \mathrm{MIC}$ concentrations.

These results are considered as indicative of irreversible and important cytoplasmic membrane damage (CARSON et al., 2002), which allows us to consider that the target of EEP is the cytoplasmic membrane.

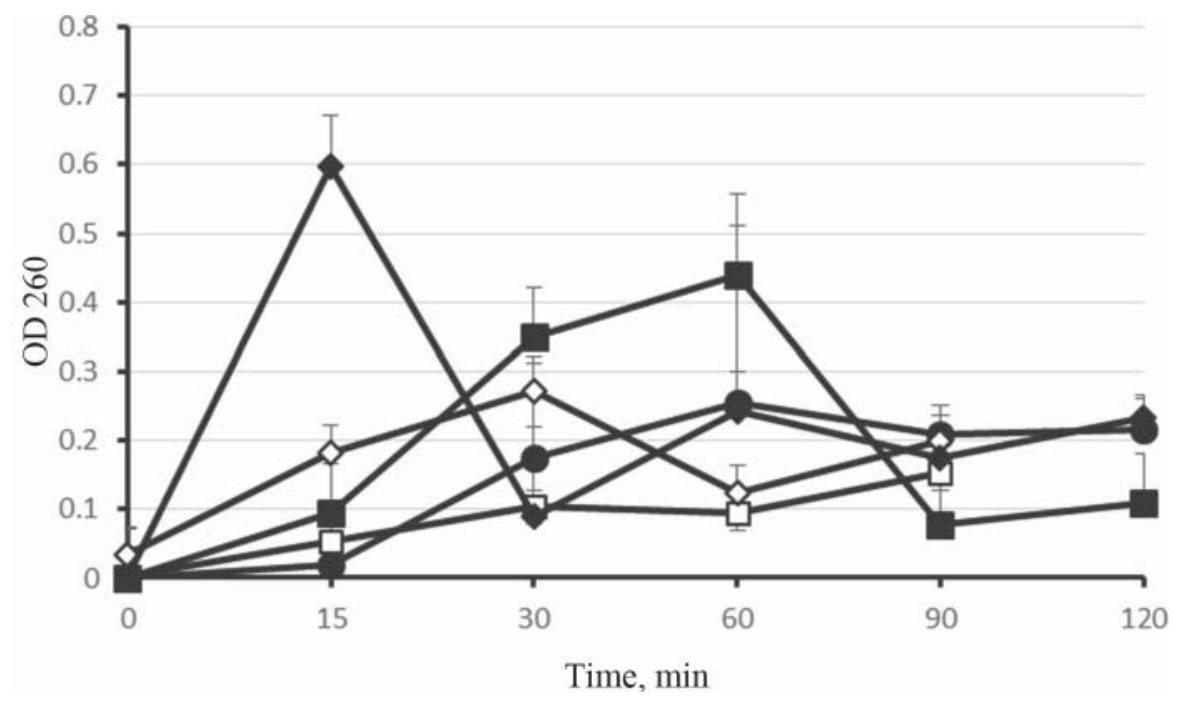

Fig. 2. The effect of EEP on nucleic leakage from $S$. aureus

$(\square)$ : control without EEP; $(\diamond)$ : with vancomycin $\left(0.5 \mathrm{mg} \mathrm{m}^{-1}\right)$ at $1 \mathrm{MIC}(\bullet)$; $2 \mathrm{MIC}(\diamond)$; and $4 \mathrm{MIC}(\bullet)$

\subsection{Potassium $(\mathrm{K}+)$ and protein leakage}

Cellular impermeability is one of the major mechanisms of intrinsic resistance of bacteria to various antibiotics. The cell membrane may be damaged and functionally disabled when bacterial suspensions are exposed to antibacterial agents, which leads to the leaking of small ions such as $\mathrm{K}^{+}$, which is considered as the primary indicator of membrane damage in microorganisms, followed by large molecules such as proteins (OLIVEIRA et al., 2015).

According to our results, an increase in potassium leakage (Fig. 3) was observed for $S$. aureus cells incubated with 4MIC concentration of EEP compared to control cells. These results indicated evident autolysis and bacterial membrane damage. The high amount of $\mathrm{K}^{+}$ leaked from untreated cells is probably a consequence of autolysis, the self-digestion of the cell wall by peptidoglycan hydrolysis (CUSHNIE \& LAMB, 2005). These results clearly indicated that the bacterial cell membrane integrity has been compromised after exposure to EEP. It may act through creating pores in the bacterial membranes due to the detergent properties of phenols and flavonoids (SARITHA et al., 2015).

A $178.67 \pm 1.27 \mu \mathrm{g} \mathrm{ml}^{-1}$ concentration of protein leaking from $S$. aureus was obtained after treatment with 4MIC concentrations of EEP for $90 \mathrm{~min}$ (Fig. 4). This concentration was higher than that obtained with vancomycin $\left(125.79 \pm 3.62 \mu \mathrm{g} \mathrm{ml}^{-1}\right)$ for the same time of treatment. 


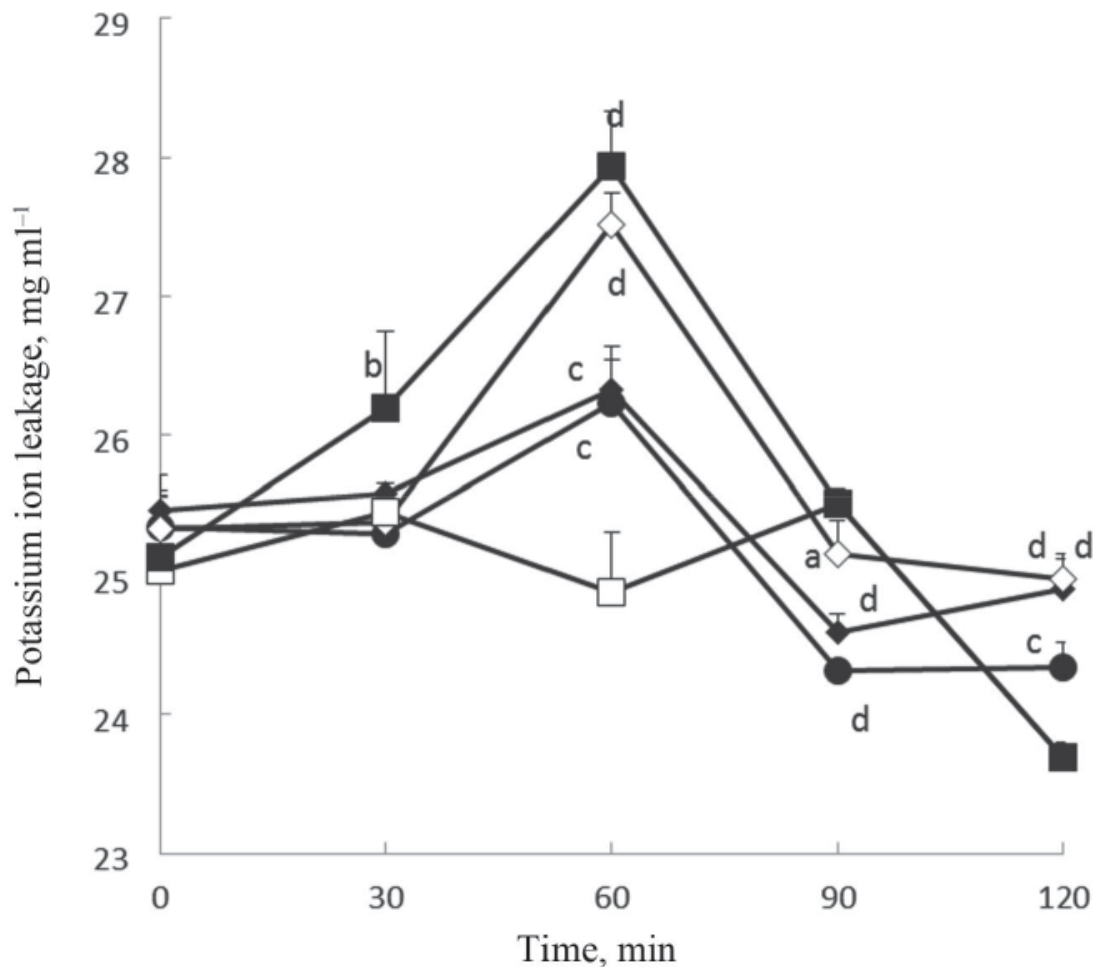

Fig. 3. The effect of EEP on potassium ion leakage from $S$. aureus

$(\square)$ : control without EEP; $(\diamond)$ : with vancomycin, $(0.5 \mathrm{mg} / \mathrm{ml})$; at1MIC $(\bullet) ; 2 \mathrm{MIC}(\diamond)$ and $4 \mathrm{MIC}(\boldsymbol{\bullet})$. Results are expressed as mean \pm standard deviation $(\mathrm{n}=3) .0 .05^{\text {' }} \mathrm{P}^{\mathrm{a}}, 0.01$ ' $\mathrm{P}^{\mathrm{b}}, 0.001^{\text {' }} \mathrm{P}^{\mathrm{c}}, 0^{\text {' }} \mathrm{P}^{\mathrm{d}}$, compared to the control

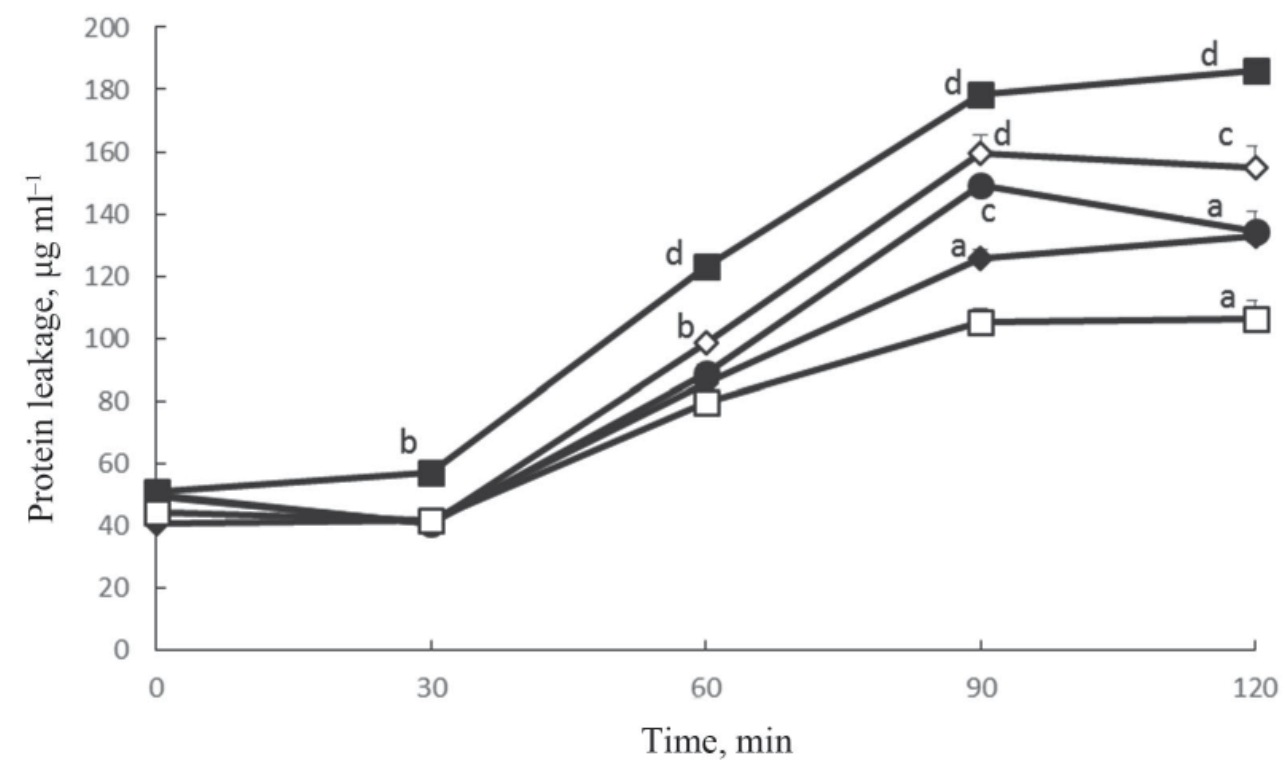

Fig. 4. The effect of EEP on protein leakage from S. aureus. Symbols as in Fig. 3. 


\subsection{Scanning Electron Microscopy (SEM)}

After exposure of $S$. aureus to EEP at different concentrations, cells were examined by scanning electron microscopy to provide structural evidence that confirms the action of EEP on $S$. aureus compared to the untreated population. Treated cultures of $S$. aureus with EEP at both studied concentrations exhibited deformed and swollen cells with disrupted cell walls (Fig. 5). The incubation of S. aureus with 2MIC demonstrated cell bursting and leakage (Fig. 5.C). All these morphological changes could not be seen in untreated cells (Fig. 5.A) that looked round and intact.
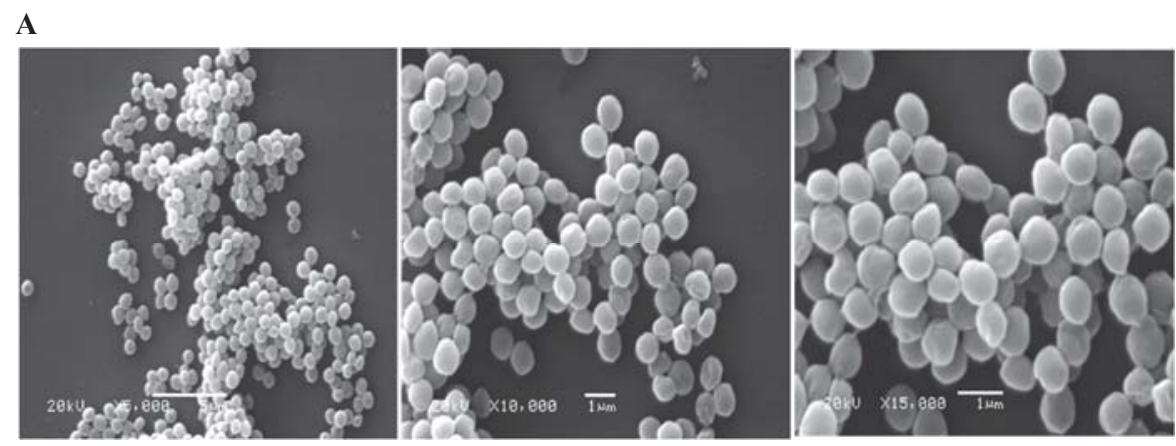

B
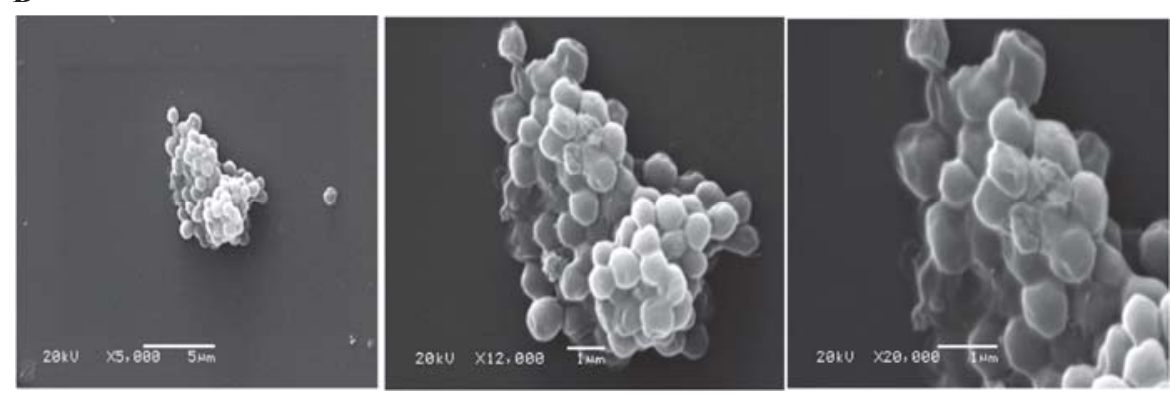

C
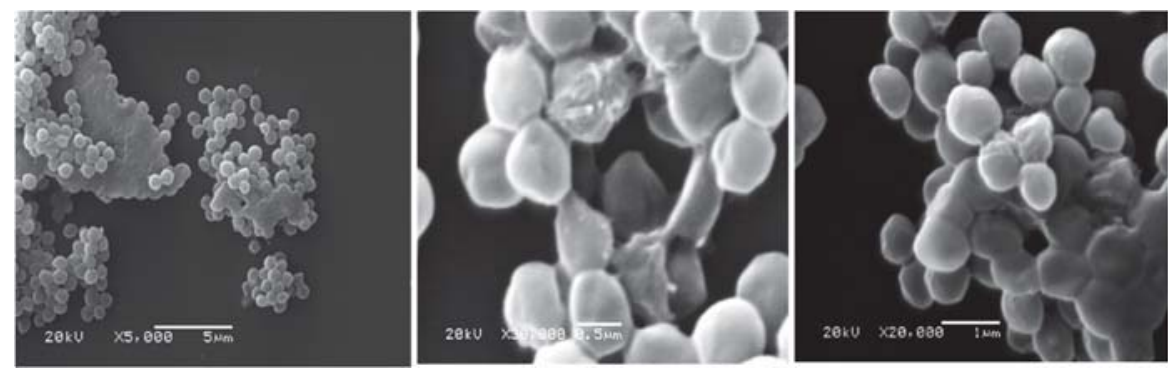

Fig. 5. Scanning electron microscopic images of S. aureus cells after $2 \mathrm{~h}$ exposure to EEP. A: Control without EEP; B: $1 \mathrm{MIC} ; \mathrm{C}: 2 \mathrm{MIC}$

These ultrastructural changes may be induced by the action of the antimicrobial compounds, causing lysis and dramatic effects on the bacterial membranes and leading to a massive leakage of cell components. The results of SEM were in agreement with some other antimicrobials treated S. aureus cells (TYAGI et al., 2015). 


\section{Conclusions}

Based on our results and findings in the literature, we confirmed that the antibacterial activity of EEP against $S$. aureus ATCC 25923 resulted from the ability to disrupt the permeability barrier of its membrane structure leading to the leakage of cellular content due to the synergy of its several constituents as demonstrated by scanning electron microscopic images. These results indicate a good potential in using propolis as a natural bio-preservative in food products. Further analyses are required to elucidate structure-activity relationships.

To the best of our knowledge, this is the first study detailing the antibacterial activity of Algerian EEP and its probable mode of action.

Conflict of interest: there is no financial/personal interest or belief.

\section{References}

Akinpelu, D.A., Alayande, K.A., Aiyegoro, O.A., Akinpelu, O.F. \& OKoh, A.I. (2015): Probable mechanisms of biocidal action of Cocos nucifera Husk extract and fractions on bacteria isolates. BMC Complem. Altern. M., 15:116, 1-9.

Akinpelu, D.A., Odewade, J.O., Aiyegoro, O.A., Ashafa, A.O.T., Akinpelu, O.F. \& Agunbiade, M.O. (2016): Biocidal effects of stem bark extract of Chrysophyllum albidium g. don on vancomycin-resistant Staphylococcus aureus. BMC Complem. Altern. M., 16:105, 1-9.

Benhanifia, M., Shimomura, K., Tsuchiya, I., Inui, S., Kumazawa, S., ... \& Benbarek, H. (2014): Chemical composition and antimicrobial activity of propolis collected from some localities of Western Algeria. Acta Alimentaria, 43, 482-488.

Borges, A., Ferreira, C., SaAvedra, M.J. \& Simões, M. (2013): Antibacterial activity and mode of action of ferulic and gallic acids against pathogenic bacteria. Microb. Drug Resist., 19, 256-265.

Carson, C.F., Mee, B.J. \& Riley, T.V (2002): Mechanism of action of Melaleuca alternifolia (tea tree) oil on Staphylococcus aureus determined by time-kill, lysis, leakage, and salt tolerance assays and electron microscopy. Antimicrob. Agents Ch., 46, 1914-1920.

Cushnie, T.P.T. \& LAmB, A.J. (2005): Detection of galangin-induced cytoplasmic membrane damage in Staphylococcus aureus by measuring potassium loss. J. Ethnopharmacol., 101, 243-248.

El-Guendouz, S., Aazza, S., Lyoussi, B., Bankova, V., Popova, M., .. \& Miguel, G. (2018): Moroccan propolis: A natural antioxidant, antibacterial, and antibiofilm against Staphylococcus aureus with no induction of resistance after continuous exposure. Evid.-Based Compl. Alt., 2018, Article ID 9759240, 19 pages.

El-Sohaimy, S. \& MaSry, S. (2014): Phenolic content, antioxidant and antimicrobial activities of Egyptian and Chinese propolis. Am.-Eurasian J. Agr. Environ. Sci., 14, 1116-1124.

Grecka, K., Kus, P.M., Okinczyc, P., Worobo, R.W., Walkusz, J. \& Szweda, P. (2019): The anti-staphylococcal potential of ethanolic Polish propolis extracts. Molecules, 24, 1-24

Ifesan, B.O.T., Joycharat, N. \& Voravuthikunchai, S.P. (2009): The mode of antistaphylococcal action of Eleutherine americana. FEMS Immunol. Med. Microbiol., 57, 193-201.

Koutsoumanis, K.P. \& Sofos, J.N. (2004): Comparative acid stress response of Listeria monocytogenes, Escherichia coli $\mathrm{O} 157$ :H7, and Salmonella typhimurium after habituation at different $\mathrm{pH}$ conditions. Lett. Appl. Microbiol., $38,321-326$.

May, J., Chan, C.H., King, A, Williams, L. \& French, G.L. (2000): Time-kill studies of tea tree oils on clinical isolates. J. Antimicrob. Chemoth., 45, 639-643.

Mirzoeva, O.K., Grishanin, R.N. \& Calder, P.C. (1997): Antimicrobial action of propolis and some of its components: The effects on growth, membrane potential and motility of bacteria. Microbiol. Res., 152, 239246.

Mohdaly, A.A.A., Mahmoud, A.A., Roby, M.H.H., Smetanska, I. \& Ramadan, M.F. (2015): Phenolic extract from propolis and bee pollen: Composition, antioxidant and antibacterial activities. J. Food Biochem., 39, 538-547.

Oliveira, D.M., Melo, F.G., Balogun, S.O., Flach, A., De Souza, E.C.A., ... \& De Oliveira Martins, D.T. (2015): Antibacterial mode of action of the hydroethanolic extract of Leonotis nepetifolia (L.) R. Br. involves bacterial membrane perturbations. J. Ethnopharmacol., 172, 356-363. 
Pedonese, F., Verani, G., Torracca, B., Turchi, B., Felicioli, A. \& Nuvoloni, R. (2019): Effect of an Italian propolis on the growth of Listeria monocytogenes, Staphylococcus aureus and Bacillus cereus in milk and whey cheese. Ital. J. Food Saf., 8, 218-222.

Popova, M., Giannopoulou, E., Skalicka-wozniak, K., Graikou, K., Widelski, J., ... \& Chinou, I. (2017): Characterization and biological evaluation of propolis from Poland. Molecules, 22, 1159.

Ríos, J.L. \& Recio, M.C. (2005): Medicinal plants and antimicrobial activity. J. Ethnopharmacol., 100, 80-84.

Saritha, K., Rajesh, A., Manjulatha, K., Setty, O.H. \& Yenugu, S. (2015): Mechanism of antibacterial action of the alcoholic extracts of Hemidesmus indicus (1.) R. Br. ex Schult, Leucas aspera (wild.), Plumbago zeylanica L., and Tridax procumbens (L.) R. Br. ex Schult. Front. Microbiol., 6, 1-9.

Segueni, N., Zellagui, A., Moussaoui, F., Lahouel, M. \& Rhouati, S. (2014): Antibacterial activity of two Algerian propolis. IJPSRR, 25(1), 106-110.

Segueni, N., Zellagui, A., Moussaoui, F., Lahouel, M. \& Rhouati, S. (2016): Flavonoids from Algerian propolis. Arab. J. Chem., 9, s425-s428.

Soltani, E., Cerezuela, R., Charef, N., Mezaache-Aichour, S., Esteban, M.A. \& Zerroug, M.M. (2017): Algerian propolis extracts: chemical composition, bactericidal activity and in vitro effects on gilthead seabream innate immune responses. Fish Shellfish Immun., 62, 57-67.

SURIYATEM, R., AURAS, R.A., RaChtANAPUn, C. \& RACHTANAPUn, P. (2018): Biodegradable rice starch/carboxymethyl chitosan films with added propolis extract for potential use as active food packaging. Polymers - Basel, 10, 954.

Tyagi, P., Singh, M., Kumari, H., Kumari, A. \& Mukhopadhyay, K. (2015): Bactericidal activity of curcumin I is associated with damaging of bacterial membrane. Plos One, 10, 1-15.

Zhang, S., IANDolo, J.J. \& Stewart, G.C. (1998): The enterotoxin D plasmid of Staphylococcus aureus encodes a second enterotoxin determinant (sej). FEMS Microbiol. Lett., 168, 227-233. 